\title{
Water Scorpions, Water Stick-Insects Ranatra spp. (Insecta: Hemiptera: Nepidae) ${ }^{1}$
}

\author{
Taryn B. Griffith and Jennifer L. Gillett-Kaufman²
}

\section{Introduction}

Commonly mistaken for other objects due to its appearance, the water stick-insect, (Figure 1) is commonly found in fresh or brackish water (a mix of salt and fresh water) (Anufriyeva et al. 2016). The genus Ranatra consists of ambush predators and will spend most of their time in water environments waiting for prey. In comparison to many other insects, they have long legs. Their ability to capture prey is limited to the length of their raptorial forearms. In the southeastern United States, these insects are commonly referred to as water scorpions, although they are not true scorpions and possess no stinging capability.

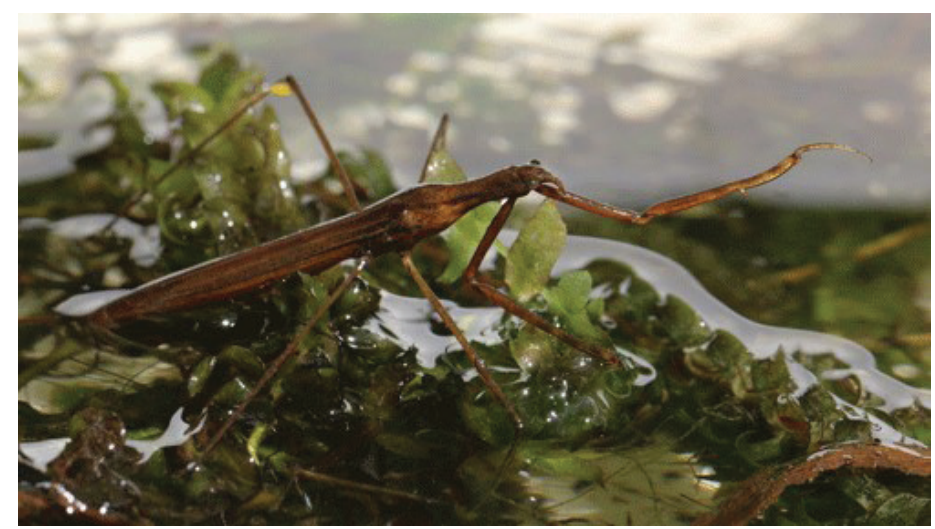

Figure 1. Adult water stick-insect, Ranatra linearis (L.).

Credits: Charles Sharp, Sharp Photography

\section{Distribution}

This genus contains around 100 species worldwide with 45 of them originating from South America, 29 from Asia, and three from Australia (Chen et al. 2004). The southern water scorpion, Ranatra australis, is the most common species of Ranatra found in Florida, it is also found in many other southern states including Virginia, Texas, and Louisiana (Herring 1951, Bick et al. 1953). They can be found near both fresh water and saline water. In Europe, specifically Crimea, Ranatra linearis is the largest animal found in hypersaline water bodies, or water at a salinity greater than 24 grams per liter (more salty than ocean water). Three specimens were found on a waterbody near Lake Tobechikskoye, Crimea in 2012 with a salinity of 110 grams per liter (Anufriyeva et al. 2016).

\section{Description}

The immatures, or nymphs, of this genus appear similar to adults, but are much smaller and wingless, as is common for many Hemipterans.

The water stick-insect is a unique looking hemipteran that can often be mistaken as a true stick insect, such as the twostriped walkingstick, Anisomorpha buprestoides (Stoll), or the grass-like mantid, Thesprotia graminis (Scudder), by the untrained eye due to their brown color and slender appearance. The water stick-insect has a long breathing

1. This document is EENY-758, one of a series of the Entomology and Nematology Department, UF/IFAS Extension. Original publication date May 2020. Visit the EDIS website at https://edis.ifas.ufl.edu for the currently supported version of this publication. This document is also available on the Featured Creatures website at http://entomology.ifas.ufl.edu/creatures.

2. Taryn B. Griffith and Jennifer L. Gillett-Kaufman, Extension scientist; Entomology and Nematology Department, UF/IFAS Extension, Gainesville, FL 32611.

The Institute of Food and Agricultural Sciences (IFAS) is an Equal Opportunity Institution authorized to provide research, educational information and other services

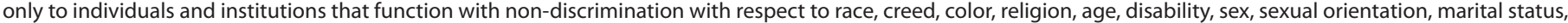

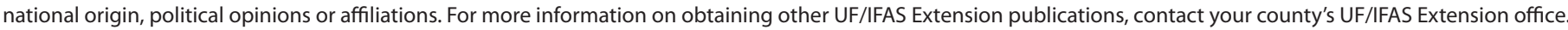
U.S. Department of Agriculture, UF/IFAS Extension Service, University of Florida, IFAS, Florida A \& M University Cooperative Extension Program, and Boards of County Commissioners Cooperating. Nick T. Place, dean for UF/IFAS Extension. 
siphon located at the end of the abdomen that is often mistaken as a stinger. The siphon is two rigid filaments pressed together, acting as a tube to enable the insect to take in air from the water surface (Figure 2). This genus has two long pairs of legs and a shorter pair of front legs. The front legs are raptorial that are specialized for grasping prey before piercing them with their rostrum or tube-like mouthpart (Figure 3).

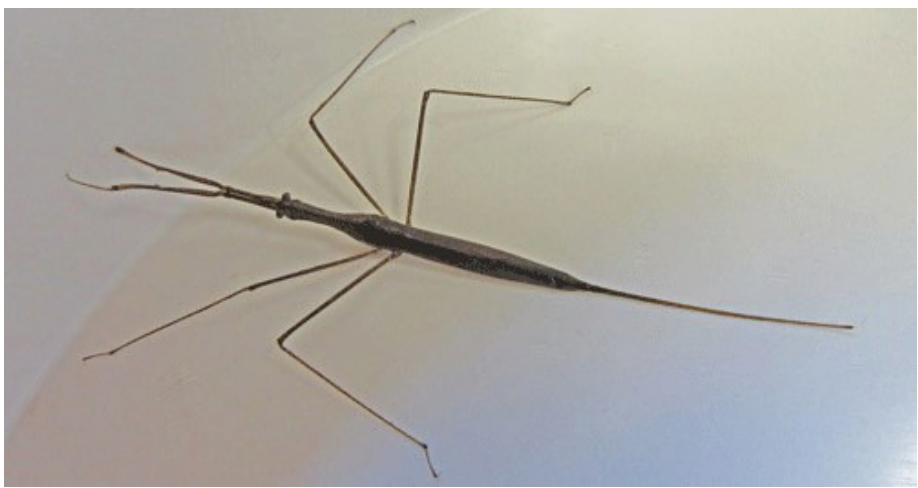

Figure 2. Adult water stick-insect.

Credits: Andrea Krava, www.metroparks.net

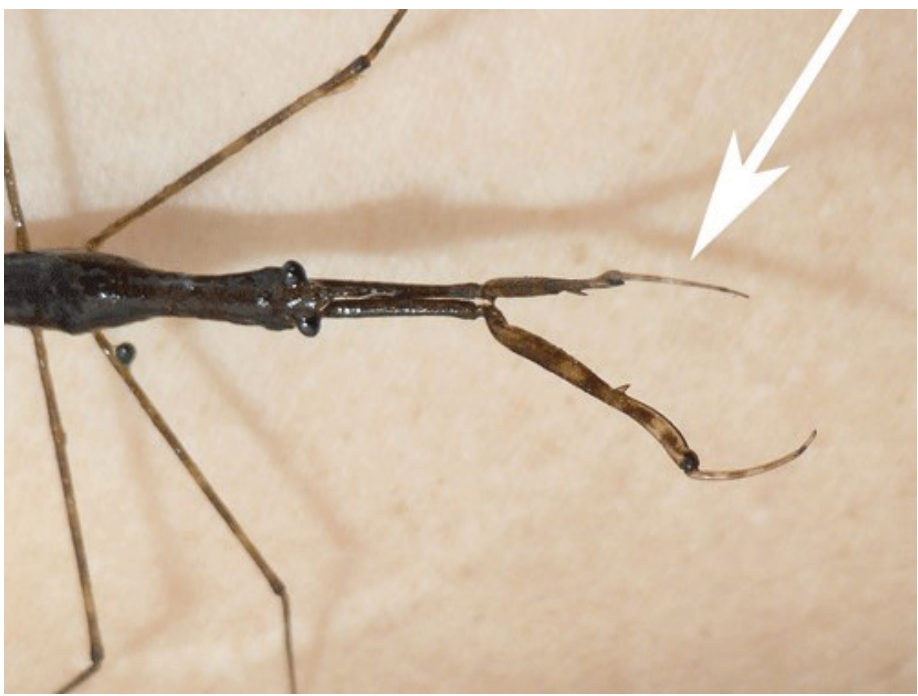

Figure 3. Water stick-insect, Ranatra australis (Fabricius), and its specialized raptorial forelimbs.

Credits: Masumi Palhof, www.inaturalist.org

Like all insects, water scorpions have antennae, but they are very short and thin, and concealed on the head. Their mouthparts are like other hemipterans, or true bugs, and consist of a straw-like structure, known as a rostrum, used for piercing and sucking fluids from their food. The adults appear to be wingless, but they possess stiff wings that slant on their backs when at rest. They are more likely to fly on warm days (Wright 1997). On average, adults are from three to three and a half inches long (Anufriyeva et al. 2016).

\section{Eggs}

Eggs are placed on vegetation by the female (Figure 4). If submerged, eggs can still respire by using an air film created by the lattice like eggshell, as carbon dioxide and oxygen can diffuse through the shell. The eggs have anterior horns used like spiracles (body openings for air intake) to breathe by breaking the water surface. Eggs hatch in the beginning of summer (Wright 1997).

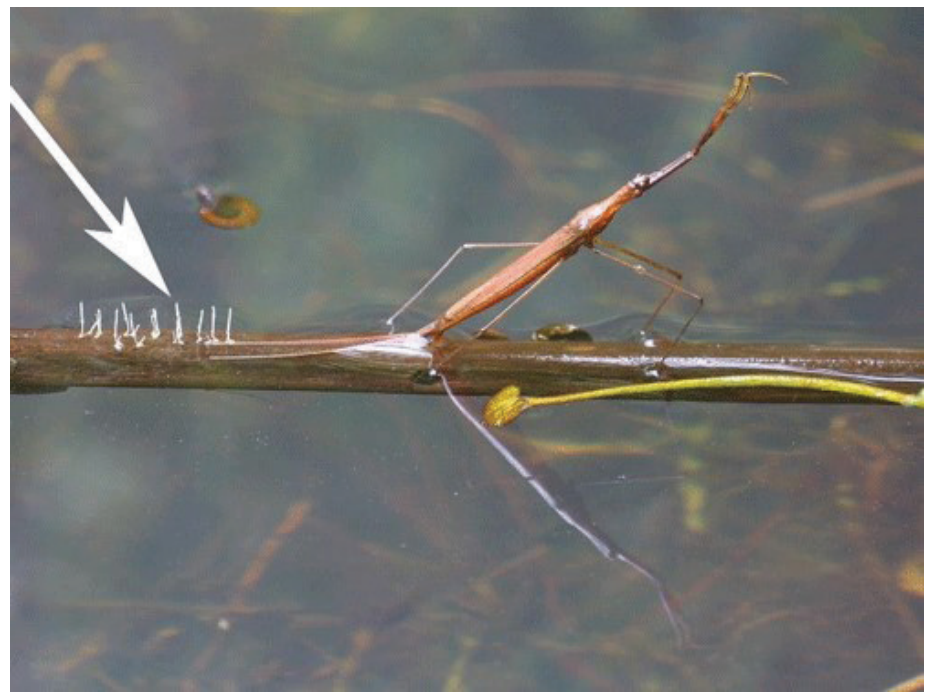

Figure 4. Water stick-insect, Ranatra linearis (L.), laying eggs. Credits: Bob, Flickr.com

\section{Nymphs}

Nymphs are active during the summer months and pass through five instars before maturing to an adult (Wright 1997). The first instar lasts five to seven days, with later instars taking longer. The fifth and final instar lasts thirteen to fourteen days (Cloarec 1980). Molting lasts approximately 20 minutes for all instars from the time the first dorsal split appears on the thorax. Nymphs emerge from these molts with their legs pointing backwards, under their body. Their legs do not stay straight and will soon fold and turn towards the front of the body. Nymphs that molt underwater will immediately surface for air.

Forelegs move independently of one another during strikes; however, this behavior decreases as the nymph matures through the instars, becoming more coordinated. After the third instar, there is a significant increase in simultaneous opening and closing of the legs when striking (Cloarec 1980).

\section{Adults}

Adults are generally active year-round except during extreme cold (Wright 1997). To breathe underwater, they trap the air with a series of water-repellant hairs, called setae, located under the forewings and abdomen (Wright 1997). 
In water containing low oxygen, such as a stagnant body of water, the insect will need to resurface more often, perhaps every few minutes, as oxygen will more easily diffuse out of the bubble. This restricts insects in these environments to shallower water depths. The insect can sense depth by using three pairs of false spiracles (Wright 1997). These spiracles are not used for breathing, but instead sense depth based on how the pressure of the water compresses these spiracles (Wright 1997).

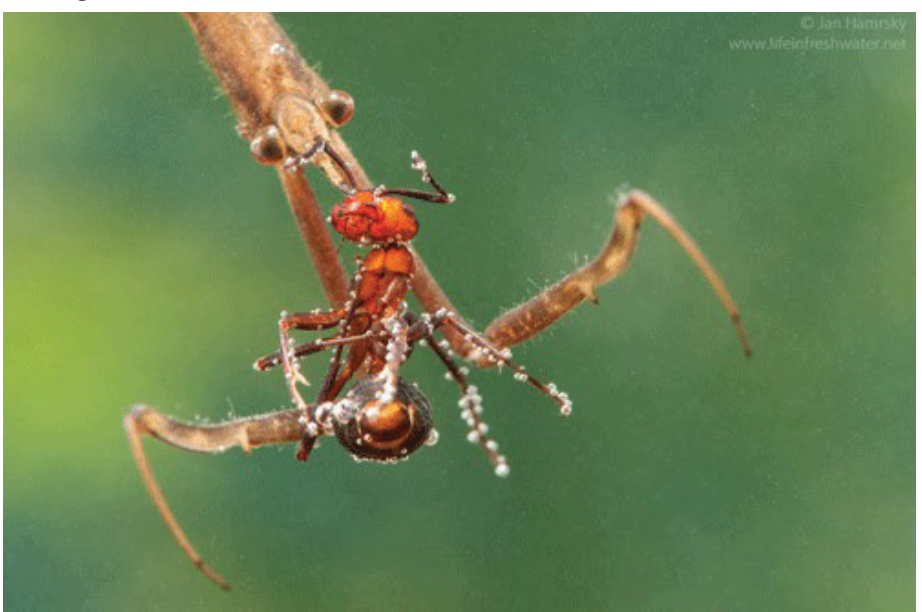

Figure 5. Water stick-insect, Ranatra linearis (L.), preying on an ant found on the water's surface.

Credits: Jan Hamrsky, Lifeinfreshwater.net

\section{Behavior}

Adults prefer to stay in shallow and densely vegetated bodies of water. The foliage allows them to hide, clinging parallel to the underside of leaves, using their second and third pairs of legs in order to catch unsuspecting prey (Wright 1997). The insect will leave its posterior legs stationary but will angle themselves so the prey is 30 degrees to its midline (Cloarec 1985). The second and third leg pairs are alternatively used to swim. The first pair of legs is used to grab prey such as Daphnia spp., ostracods (seed shrimp), small tadpoles, and fish. Prey also includes insects such as notonectids (backswimmers), corixids (water boatmen), and mosquito larvae (Bailey 1986). If the attempt of capturing the prey is a failure, the water-stick insect will attempt again if the prey is still close, this can result in up to three additional strikes in a two-second period. Once captured, venom is delivered to their prey, causing tremors and eventually paralysis (Bailey 1986).

\section{Selected References}

Anufriyeva YV, Shadrin NV. 2016. "First record of Ranatra linearis (Hemiptera, Nepidae) in hypersaline water bodies of the Crimea." Hydrobiological Journal 52: 56-61.

Bailey P. 1986. "The feeding behavior of a sit-and-wait predator, Ranatra dispar, (Heteroptera: Nepidae): Description of behavioural components of prey capture, and the effect of food deprivation on predator arousal and capture dynamics." Behavior 97: 66-93.

Bick G, Hornuff L, Lambremont E. 1953. "An ecological reconnaissance of a natural acid stream in southern Louisiana." Journal of the Tennessee Academy of Science 28: 229.

Chen P, Nieser N, Ho JZ. 2004. "Review of Chinese Ranatrinae (Hemiptera: Nepidae), with descriptions of four new species of Ranatra Fabricius." Tijdschrift voor Entomologie 147: 81-102.

Cloarec A. 1980. "Post-molt behavior in the water-stick insect Ranatra linearis." Behavior 70: 304-324.

Cloarec A. 1985. "Distance and size discrimination in a water stick insect, Ranatra linearis (Heteroptera)." Journal of Experimental Biology 120: 59-77.

Herring J. 1951. "The aquatic and semiaquatic Hemiptera of north Florida. Part 3: Nepidae, Belostomatidae, Notonectidae, Pleidae, and Corixidae." Florida Entomologist 34: $18-29$.

Wright J. 1997. Water scorpions. Northern State University. The Natural Source. https://www3.northern.edu/natsource/ INVERT1/Waters1.htm Accessed September 7, 2019. 